\title{
Melalui Pembelajaran Kontekstual Model Pengajaran Berbasis Masalah Untuk Meningkatkan Prestasi Dan Penguasaan Materi Persamaan Dasar Akuntansi
}

\author{
SAIFULLAH, SE \\ (Guru SMA Negeri 1 Aceh Barat Daya Provinsi Aceh)
}

\begin{abstract}
Abstrak - Untuk bisa mempelajari sesuatu dengan baik, kita perlu mendengar,melihat, mengajukan pertanyaan tentangnya, dan membahasnya dengan orang lain. Bukan Cuma itu, siswa perlu "mengerjakannya", yakni menggambarkan sesuatu dengan cara mereka sendiri, menunjukkan contohnya, mencoba mempraktekkan keterampilan dan mengerjakan tugas yang menuntut pengetahuan yang telah mereka dapatkan. Penelitian Tindakan Kelas (PTK) bertujuan untuk mengetahui peningkatan prestasi dan penguasaan materi belajar siswa serta aktifitas ,motivasi siswa mengenai penerapan pembelajaran Ekonomi pada materi persamaan dasar Akutansi, Penelitian ini dilaksanakan dalam dua siklus, Subyek penelitian adalah siswa kelas XII.IPS.2 SMA Negeri 1 Aceh Barat Daya tahun pelajaran 2018/2019. jumlah siswa sebanyak 31 siswa 19 siswa laki-laki dan 12 siswa perempuan. Penelitian ini menggunakan penelitian tindakan (action research) sebanyak dua putaran. Setian putaran terdiri dari empat tahap yaitu: rancangan, kegiatan dan pengamatan, refleksi, dan refisi. Sasaran penelitian ini adalh siswa kelas XII.IPS.2 SMA Negeri 1 Aceh Barat Daya. Data yang diperoleh berupa hasil tes formatif, lembar observasi kegiatan belajar mengajar. Hasil penelitian menunjukkan data prestasi belajar siswa mengalami peningkatan yaitu dapat terlihat dari hasil evaluasi pada siklus I memperoleh nilai rata rata 69,03 dan pada siklus II meningkat menjadi perolehan nilai rata rata 80,64 ketuntasan belajar klasikal 90,32\%.. Hasil analisis data tersebut menunjukkan bahwa penggunaan Pembelajaran Kontekstual Model Pengajaran Berbasis Masalah dapat meningkatkan prestasi belajar siswa. Kesimpulan dari penelitian ini adalah pembelajaran kontekstual berbasis masalah dapat berpengaruh positif terhadap motivasi belajar Siswa kelas XII.IPS.2 SMA Negeri 1 Aceh Barat Daya serta model pembelajaran ini dapat digunakan sebagai salah satu alternative pembelajaran Ekonomi..
\end{abstract}

Kata kunci :Prestasi belajar, Pembelajaran Kontekstual Model Pengajaran Berbasis Masalah 


\section{Pendahuluan}

Pembangunan Nasional di bidang pengembangan sumberdaya manusia Indonesia yang berkualitas melalui pendidikan merupakan upaya yang sungguh-sungguh dan terus-menerus dilakukan untuk mewujudkan manusia Indonesia seutuhnya. Sumberdaya yang berkualitas akan menentukan mutu kehidupan pribadi, masyarakat, dan bangsa dalam rangka mengantisipasi, mengatasi persoalan-persoalan, dan tantangantantangan yang terjadi dalam masyarakat pada kini dan masa depan[1]. Salah satu permasalahan yang dihadapi oleh bangsa Indonesia adalah rendahnya mutu pendidikan, khususnya pendidikan dasar dan menengah. Berbagai usaha telah dilakukan untuk menigkatkan mutu pendidikan nasional, antara lain melalui berbagai pelatihan dan peningkatan kualitas guru, penyempurnaan kurikulum, pengadaan buku dan alat pelajaran, perbaikan sarana dan prasarana pendidikan lain, dan peningkatan mutu manajemen sekolah, namun demikian, berbagai indikator mutu pendidikan belum menunjukkan peningkatan yang memadai[2].

Upaya peningkatan kualitas pendidikan di Indonesia tidak pernah berhenti. Berbagai terobosan baru terus dilakukan oleh pemerintah melalui Kemendiknas[3]. Upaya itu antara lain dalam pengelolaan sekolah, peningkatan sumber daya tenaga pendidikan, pengembangan/penulisan materi ajar, serta pengembangan paradigma baru dengan metodologi pengajaran. Mengajar bukan semata persoalan menceritakan. Belajar bukanlah konsekuensi otomatis dari perenungan informasi ke dalam benak siswa. Belajar memerlukan keterlibatan mental dan kerja siswa sendiri. Penjelasan dan pemeragaan semata tidak akan membuahkan hasil belajar yang langgeng. Yang bisa membuahkan hasil belajar yang langgeng hanyalah kegiatan belajar aktif[4].

Apa yang menjadikan belajar aktif? Agar belajar menjadi aktif siswa harus mengerjakan banyak sekali tugas. Mereka harus menggunakan otak, mengkaji gagasan, memecahkan masalah, dan menerapkan apa yang mereka pelajari. Belajar akif harus gesit, menyenangkan, bersemangat dan penuh gairah. Siswa bahkan sering meninggalkan tempat duduk mereka, bergerak leluasa dan berfikir keras (moving about dan thinking aloud)[5]. Untuk bisa mempelajari sesuatu dengan baik, kita perlu mendengar, melihat, mengajukan pertanyaan tentangnya, dan membahasnya dengan orang lain. Bukan Cuma itu, siswa perlu "mengerjakannya", yakni menggambarkan sesuatu dengan cara mereka sendiri, menunjukkan contohnya, mencoba mempraktekkan keterampilan, dan mengerjakan tugas yang menuntut pengetahuan yang telah atau harus mereka dapatkan[6].

Dengan menyadari gejala-gejala atau kenyataan tersebut diatas, maka dalam penelitian ini penulis penulis mengambil judul "Melalui Pembelajaran Kontekstual Model Pengajaran Berbasis Masalah Untuk Meningkatkan Prestasi dan Penguasaan Materi Persamaan Dasar Akuntansi pada siswa kelas XII.IPS.2 di SMA Negeri 1 Aceh Darat Daya.

Bertitik tolak dari latar belakang diatas maka penulis merumuskan permasalahnnya sebagi berikut:

1. Apakah ada peningkatan prestasi dan penguasaan materi belajar Persamaan Dasar Akuntansi dengan diterapkannya metode pembelajaran kontektual model pembelajarn berbasis masalah?

2. Apakah ada pengaruh penggunaan metode pembelajaran kontektual model pembelajarn berbasis masalah terhadap motivasi belajar siswa pada pelajaran Ekonomi materi Persamaan Dasar Akuntansi?

Sesuai dengan permasalahan di atas, penelitian ini bertujuan untuk:

1. Mengetahui peningkatan prestasi dan penguasaan materi belajar Persamaan Dasar Akuntansi dengan diterapkannya metode pembelajaran kontektual model pembelajarn berbasis masalah.

2. Mengetahui pengaruh motivasi belajar siswa setelah diterapkan metode pembelajaran kontektual model pembelajarn berbasis masalah pada pelajaran Ekonomi materi Persamaan Dasar Akuntansi.

\section{Tinjauan Pustaka}

Pengertian belajar sudah banyak dikemukakan dalam kepustakaan. Yang dimaksud belajar yaitu perbuatan murid dalam bidang material, formal serta fungsional pada umumnya dan bidang intelektual pada khususnya. Jadi belajar merupakan hal yang pokok. Belajar merupakan suatu perubahan pada sikap dan tingkah laku yang lebih baik, tetapi kemungkinan mengarah pada tingkah laku yang lebih buruk. Untuk dapat disebut belajar, maka perubahan harus merupakan akhir dari pada periode yang cukup panjang[7]. Berapa lama waktu itu berlangsung sulit ditentukan dengan pasti, tetapi perubahan itu hendaklah merupakan akhir dari suatu periode yang mungkin berlangsung berhari-hari, berminggu-minggu, berbulan-bulan atau bertahun-tahun. Belajar merupakan suatu proses yang tideak dapat dilihat dengan nyata proses itu terjadi dalam diri seserorang yang sedang mengalami belajar[8]. Jadi yang dimaksud dengan belajar bukan tingkah laku yang nampak, tetapi prosesnya terjadi secara internal di dalam diri individu dalam mengusahakan memperoleh hubungan-hubungan baru.

Sebelum dijelaskan pengertian mengenai prestasi belajar, terlebih dahulu akan dikemukakan tentang pengertian prestasi. Prestasi adalah hasil yang telah dicapai. Dengan demikian bahwa prestasi merupakan hasil yang telah dicapai oleh seseorang setelah melakukan sesuatu pekerjaan/aktivitas tertentu[9]. Jadi prestasi adalah hasil yang telah dicapai oleh karena itu semua individu dengan adanya belajar hasilnya dapat dicapai. Setiap individu belajar menginginkan hasil yang yang sebaik mungkin. Oleh karena itu setiap individu harus 
belajar dengan sebaik-baiknya supaya prestasinya berhasil dengan baik. Sedang pengertian prestasi juga ada yang mengatakan prestasi adalah kemampuan. Kemampuan di sini berarti yan dimampui individu dalam mengerjakan sesuatu[10].

Pengajaran berbasis masalah (Problem-Based Learning) adalah suatu pandekatan pengajaran yang menggunakan masalah dunia nyata sebagai suatu konteks bagi siswa untuk belajar tentang cara berpikir kritis dan keterampilan pemecahan masalah, serta untuk memperoleh pengetahuan dan konsep yang esensial dari materi pelajaran. Pengajaran masalah digunakan untuk merangsang berpikir tingkat tinggi dalam situasi berorientasi masalah, termasuk di dalamnya belajar bagaimana belajar[11]. Menurut Ibrahim dan Nur (2000), "Pengajaran berbasis masalah dikenal dengan nama lain seperti Project-Based Teacihg (Pembelajaran Proyek), Experienced-Based Education (Pendidikan berdasarkan pengalaman), Authentic Learning (Pembelajaran Autentik), dan Achoered Instruction (Pembelajaran berakar pada kehidupan nyata)"[12].

Peran guru dalam pengajaran berbasis masalah adalah menyajikan masalah, mengajukan pertanyaan, dan memfasilitasi penyelidikan dan dialog. Pengajaran berbasis masalah tidak dapat dilaksanakan tanpa guru mengembangkan lingkungan kelas yang memungkinkan terjadinya pertukaran ide secara terbuka. Secara garis besar pengajaran berbasis masalah terdiri dari menyajikan kepada siswa situasi masalah yang autentik dan bermakna yang dapat memberikan kemudahan kepada mereka untuk melakukan penyelidikan[13].

1. Berbagai pengembangan pengajaran berbasis masalah telah mencoba menunjukkan cirri-ciri pengajaran berbasis masalah yaitu pengajuan pertanyaa atau masalah dan penyelidikan autentik. Pengajaran berbasis masalah dirancang untuk membantu guru memberikan informasi sebanyak-banyaknya kepada siswa. Pengajaran berbasis masalah dikembangkan terutama untuk membantu siswa mengembangkan kemampuan berpikir, pemecahan masalah, dan keterampilan intelektual, belajar tentang berbagai peran orang dewasa melalui pelibatan mereka dalam pengalaman nyata atau simulasi, dan menjadikan pembelajar yang otonom dan mandiri. Uraian rinci terhdap ketiga tujuan itu dijelaskan lebih jauh oleh Ibrahim dan Nur (2000) yaitu Keteramplan Berpikir dan Keterampilan Pemecahan Masalah.

\section{Tahapan Pengajaran Berbasis Masalah}

Pengajaran berbasis masalah biasanya terdiri dari lima tahapan utama yang dimulai dengan guru memperkenalkan siswa dengan suatu situasi masalah dan diakhiri dengan penyajian dan analisis hasil kerja siswa.

\begin{tabular}{|l|}
\hline \multicolumn{1}{|c|}{ Tahapan } \\
\hline Tahap 1 \\
Orientasi siswa kepada masalah \\
\hline Tahap 2 \\
Mengorganisasi siswa untuk belajar \\
\hline Tahap 3 \\
Membimbing penyelidikan individual dan \\
kelompok \\
\hline Tahap 4 \\
Mengembangkan dan menyajikan hasil karya \\
\hline Tahap 5 \\
Menganalisa dan mengevaluasi proses \\
pemecahan maslah \\
\hline
\end{tabular}

\section{Hipotesis}

Adapun hipotesis dalam penelitian ini adalah: "Melalui Pembelajaran Kontekstual Model Pengajaran Berbasis Masalah Dapat Meningkatkan Prestasi dan Penguasaan Materi Persamaan dasar Akuntansi pada siswa kelas XII.IPS.2 di SMA Negeri 1 Aceh Darat Daya.

\section{Metodelogi Penelitian}

Penelitian dilaksanakan selama 3 bulan, mulai tanggal 04 Agustus 2018 sampai dengan tanggal 30 Oktober 2018. Pelaksanaan penelitian dilakukan pada hari-hari efektif sesuai dengan jadwal jam pelajaran. Tempat penelitian pembelajaran dilaksanakan adalah di SMA Negeri 1 Aceh Barat Daya.

Berdasarkan judul penelitian yaitu "Melalui Pembelajaran Kontekstual Model Pengajaran Berbasis Masalah Untuk Meningkatkan Prestasi dan Penguasaan Materi Persamaan dasar Akuntansi pada siswa kelas XII.IPS. 2 di SMA Negeri 1 Aceh Darat Daya " maka subyek penelitiannya siswa-siswi Kelas XII.IPS.2 SMA Negeri 1 Aceh Barat Daya sejumlah 31 siswa terdiri dari 12 siswi perempuan dan 19 siswa laki-laki. 
Sumber data dalam penelitian ini adalah siswa, sebagai subyek penelitian. Data yang dikumpulkan dari siswa meliputi data hasil tes tertulis. Tes tertulis dilaksanakan pada setiap akhir siklus yang terdiri atas materi tenaga kerja dan pembangunan ekonomi.

Model penelitian dalam penelitian ini adalah Penelitian Tindakan Kelas (PTK), dengan menggunakan model Kemmis dan Mc. Taggart. Penelitian ini memiliki tahapan berupa siklus. Model PTK Kemmis dan Mc. Taggart menjelaskan bahwa dalam satu siklus terdiri dari empat komponen yang dimulai dengan rencana, tindakan, pengamatan, refleksi (Basrowi, 2008: 68). Setelah satu siklus diimplementasikan khususnya sesudah adanya refleksi, kemudian diikuti dengan adanya perencanaan ulang yang dilaksanakan dalam bentuk siklus tersendiri, demikian seterusnya atau dengan beberapa siklus.

\subsection{Teknik Pengumpulan Data}

\section{a. Testing}

Tes diberikan kepada siswa sebagai tes awal/tes diagnostik adalah tes berbentuk uraian yang berjumlah 5 soal. Hasil tes awal yang diperoleh kemudian dianalisis dan digunakan untuk: a) mengetahui tingkat kemampuan siswa pada materi Persamaan Dasar Akuntansi , b) menentukan kelompok diskusi siswa, c) mengetahui kesulitan yang dialami peserta didik pada materi Persamaan Dasar Akuntansi. Pada akhir pembelajaran diberikan tes akhir (post tes) untuk: a) mengetahui tingkat kemampuan peserta didik pada Persamaan Dasar Akuntansi, b) mengetahui kesulitan yang dialami peserta didik pada materi Persamaan Dasar Akuntansi.

b. Wawancara

Dalam hal ini yang menjadi sasaran wawancara adalah siswa yang berkemampuan rendah sebagai subyek penelitian untuk mengetahui kesulitannya dalam memahami materi pelajaran. Hasil tes dan wawancara digunakan sebagai indikator dalam menentukan tindakan yang tepat untuk meningkatkan hasil belajar ekonomi siswa dengan menerapkan model Pengajaran Berbasis Masalah.

\section{Observasi}

Observasi dilakukan kepada seluruh siswa saat kegiatan belajar mengajar berlangsung, tujuannya untuk mengetahui aktifitas belajar, keaktifan, dan kemampuan pemecahan masalah siswa dalam kelompok saat kegiatan belajar mengajar berlangsung. Guru ekonomi bertindak sebagai observer yang mengamati aktifitas pembelajaran yang berpedoman pada lembar observasi yang telah disiapkan serta memberikan penilaian berdasarkan pengamatan yang dilakukan untuk membantu peneliti mengumpulkan data. Hasil observasi dianalisis secara deskriptif. Proses pembelajaran dikatakan efektif jika pelaksanaan pembelajaran minimal berjalan dengan baik.

\section{Hasil Penelitian Dan Pembahasan}

\subsection{Hasil Penelitian}

a. Pra Siklus

Pra Siklus merupakan kondisi awal peserta didik sebelum peneliti melakukan penelitian di dalam kelas dengan menggunakan pola konvensional. Hasil data pra Siklus yang diperoleh peneliti bersama dengan Observer dalam melakukan evaluasi mengenai model pembelajaran yang digunakan dianggap belum sesuai, sehingga perlu diadakan perbaikan dari proses pembelajaran tersebut. Melihat kondisi pembelajaran yang monoton, suasana pembelajaran tampak kaku, berdampak pada tingkat hasil belajar siswa yang diperoleh dari materi Persamaan dasar Akuntansi pelajaran Ekonom belum berhasil mencapai nilai Kriteria Ketuntasan minimal (KKM) sebesar 70. Data seengkapnya mengeani hasil belajar tersebut dapat dilihat pada table berikut:

\begin{tabular}{|c|c|c|}
\hline $\begin{array}{l}\mathrm{N} \\
\mathrm{O}\end{array}$ & Uraian & $\begin{array}{l}\text { Hasil Pra } \\
\text { Siklus }\end{array}$ \\
\hline 1 & $\begin{array}{l}\text { Nilai rata-rata tes } \\
\text { formatif }\end{array}$ & 56,45 \\
\hline 2 & $\begin{array}{c}\text { Jumlah siswa yang tuntas } \\
\text { belajar }\end{array}$ & 9 \\
\hline 3 & $\begin{array}{c}\text { Presentase ketuntasan } \\
\text { belajar }\end{array}$ & 29,03 \\
\hline
\end{tabular}

Dari data di atas dapat di jelaskan bahwa sebelum menggunakan model pengajaran berbasis masalah diperoleh nilai rata-rata adalah 56,45 dengan persentase ketuntasan mencapai 29,03atau sebanyak 9 peserta didik dari 31 pesertta didik yang tuntas belajar. Hasil tersebut menunjukkan bahwa pada Pra Siklus Secara klasikal peserta didik belum tuntas belajar. Karena baru 29,03\% atau 9 peserta didik yang mencapai KKM , 
sehingga masih terdapat 22 dari 31 peseta didik yang belum tuntas. Hasil belajar tersebut masih kecil dari persentase ketuntasan klasikal dalam pembelajaran Ekonomi yang dikehendaki sebesar $85 \%$.

b. Siklus I

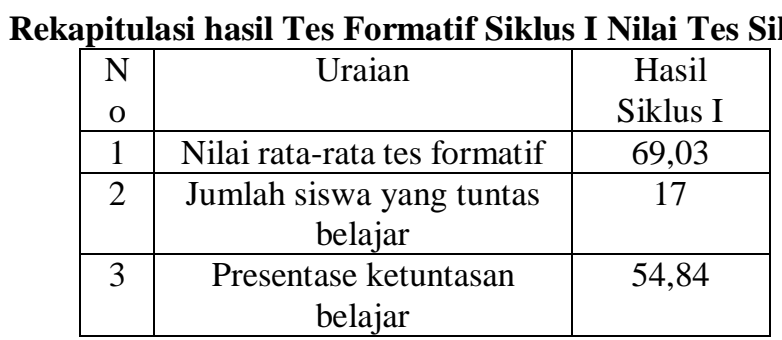

Berdasarkan tabel diatas dapat dijelaskan dengan penggunan model pengajaran berbasis masalah, maka diperoleh nilai rata-rata hasil belajar peserta didik adalah 69,03 dan ketuntasan belajar mencapai 54,84\% atau hanya beru 17 peserta didik dari 31 peserta didik yang tuntas belajar. Hasil tersebut menunjukkan bahwa pada siklus I secara klasikal peserta didik belum tuntas belajar, karena peserta didik yang memperoleh nilai $\geq 70$ hanya sebesar 54,84\% masih lebih kecil dari persentase ketuntasan yang dikehendaki yaitu $85 \%$. Hal ini deisebabkan karena peserta didik belum terbiasa dengan model pembelajaran berbasis masalah.

c. Siklus II

Rekapitulasi Hasil tes Formatif Siklus II

\begin{tabular}{|c|c|c|}
\hline $\begin{array}{l}\mathrm{N} \\
\mathrm{O}\end{array}$ & Uraian & $\begin{array}{l}\text { Hasil } \\
\text { Siklus II }\end{array}$ \\
\hline 1 & Nilai rata-rata tes formatif & 80,64 \\
\hline 2 & $\begin{array}{c}\text { Jumlah siswa yang tuntas } \\
\text { belajar }\end{array}$ & 28 \\
\hline 3 & $\begin{array}{c}\text { Presentase ketuntasan } \\
\text { belajar }\end{array}$ & 90,32 \\
\hline
\end{tabular}

Berdasarkan tabel diatas diperoleh nilai rata-rata hasil belajar peserta sebesar 80,64 dan dari 31 peserta didik yang tuntas belajar sebanyak 28 atau 80,64\% dan masih ada 3 peserta didik atau 9,68\% yang belum mencapai ketuntasan belajar. Maka secara klasikal sudah termasuk katagori tuntas. Hasil pembelajaran pada Siklus II inimengalami peningkatan yang signifikan dari Siklus I, hal ini disebabkan oleh peningkatan kemampuan pesertta didik dan pendidik dalam proses belajar mengajar selama kegiatan pembelajaran berlangsung.

\subsection{Pembahasan}

Dari hasil penelitian, dapat dilihat dan telah terjadi peningkatan hasil belajar materi Persamaan dasar Akuntansi pada siswa kelas XII.IPS-2 SMA Negeri 1 Aceh Barat Daya pada semester 1 tahun 2018 melalui Pembelajaran Kontekstual Model Pengajaran Berbasis Masalah. Peningkatan nilai rata- rata yaitu 54,45 pada kondisi awal menjadi 69,03 pada siklus I dan menjadi 80,64 pada siklus II. Nilai rata-rata siklus I meningkat $22,29 \%$ dari kondisi awal, nilai rata-rata siklus II meningkat $19,11 \%$ dari siklus I. Sedangkan ketuntasan belajar pada siklus I ada peningkatan sebesar 47,06\% dari kondisi awal, siklus II meningkat 39,56\% dari siklus I. Peningkatan nilai rata-rata kelas secara keseluruhan sebesar 43,29\%. Pada akhir pembelajaran terdapat perubahan positif pada siswa mengenai materi Persamaan dasar Akuntansi. Dengan menerapkan Pembelajaran Kontekstual Model Pengajaran Berbasis Masalah ternyata mampu meningkatkan prestasi dan penguasaan belajar siswa pada kompetensi dasar Persamaan dasar Akuntansi.

\section{Penutup}

\subsection{Kesimpulan}

Dari hasil kegiatan pembelajaran yang telah dilakukan selama dua siklus, dan berdasarkan seluruh pembahasan serta analisis yang telah dilakukan dapat disimpulkan sebagai berikut:

1. Prestasi dan penguasaan belajar siswa kelas XII.IPS.2 semester 1 SMA Negeri 1 Aceh Barat Daya pada pelajaran Ekonomi materi Persamaan dasar Akuntansi dapat ditingkatkan dengan menerapkan Pembelajaran Kontekstual Model Pengajaran Berbasis Masalah, ini ditunjukkan oleh peningkatan rata-rata nilai tes akhir siswa dari 69,03 pada siklus I menjadi 80,64 pada siklus II, dan ketuntasan belajar siswa meningkat dari 54,84\% pada siklus I menjadi $90,32 \%$ pada siklus II. 
2. Pembelajaran kontekstual berbasis masalah dapat berpengaruh positif terhadap motivasi belajar Siswa kelas XII.IPS.2 SMA Negeri 1 Aceh Barat Daya serta model pembelajaran ini dapat digunakan sebagai salah satu alternatif pembelajaran Ekonomi.

\subsection{Saran}

Dari hasil penelitian yang diperoleh dari uraian sebelumnya agar proses belajar mengajar pelajaran Ekonomi lebih efektif dan lebih memberikan hasil yang optimal bagi siswa, maka disampaikan saran sebagai berikut:

1. Untuk melaksanakan Pembelajaran Kontekstual Model Pengajaran Berbasis Masalah memerlukan persiapan yang cukup matang, sehingga guru harus mampu menentukan atau memilih topik yang benarbenar bisa diterapkan dengan Pembelajaran Kontekstual Model Pengajaran Berbasis Masalah dalam proses belajar mengajar sehingga diperoleh prestasi yang optimal.

2. Dalam rangka meningkatkan prestasi dan penguasaan belajar siswa, guru hendaknya lebih sering melatih siswa dengan berbagai metode/model pengajaran yang sesuai, walau dalam taraf yang sederhana. 


\section{Daftar Pustaka}

[1]. Ali, Muhammad. 1996. Guru Dalam Proses Belajar Mengajar. Bandung: Sinar Baru Algesindon.

[2]. Daroeso, Bambang. 1989. Dasar dan Konsep Pendidikan Moral Pancasila. Semarang: Aneka Ilmu.

[3]. Dayan, Anto. 1972. Pengantar Metode Statistik Deskriptif, tt. Lembaga Penelitian Pendidian dan Penerangan Ekonomi.

[4]. Hadi, Sutrisno. 1998. Metodologi Research, Jilid 1. Yogyakarta: YP. Fak. Psikologi UGM.

[5]. Melvin, L. Siberman. 2004. Aktif Learning 101 Cara Belajar Siswa Aktif. Bandung: Nusamedia dan Nuansa.

[6]. Ngalim, Purwanto M. 1990. Psikologi Pendidikan. Bandung: PT. Remaja Rosdakarya.

[7]. Riduwan. 2000. Belajar Mudah Penelitian untuk Guru-Karyawan dan Peneliti Pemula. Bandung: Alfabeta.

[8]. Sukmadinata, Nana Syaodih. 2000. Metode Penelitian Pendidikan. Bandung: PT. Remaja Rosdakarya.

[9]. Surakhmad, Winarno. 1990. Metode Pengajaran Nasional. Bandung: Jemmars.

[10]. Ibrahim dan Nur (2000). Pengaruh pembelajaran Inkuiri Terbimbing Terhadap Keterampilan Proses Sains Siswa. Jakarta: Skripsi pada FITK UIN Syarif Hidayatullah Jakarta: tidak diterbitkan.

[11]. Peraturan Menteri Pendidikan Nasional Nomor 22 Tahun 2006 Tentang Standar Isi untuk Satuan Pendidikan Dasar dan Menengah. Bandung: Fokusmedia.

[12]. Rostiyah N.K 2001. Strategi belajar Mengajar. Jakarta. Rineka Cipta.

[13]. Resnick. 1987. Pengaruh Contextual Teaching and Learning Terhadap Hasil Belajar Siswa. Bandung: skripsi FPMIPA UPI Bandung : tidak diterbitkan.

[14]. Kemmis, S. da Mc. Taggart, R. 1988. The Action Research Planner. Victoria Dearcin University Press.

[15]. Undang-Undang Republik Indonesia Nomor 20 Tahun 2003 tentang Sistem Pendidikan Nasional.

[16]. Poedjawijatna. 1991. Tahu dan Pengetahuan. Jakarta: Rineka Cipta.

[17]. Slamet. 1991. Belajar dan faktor-faktor yang mempengaruhi, Rinekat Cipta, Jakarta 